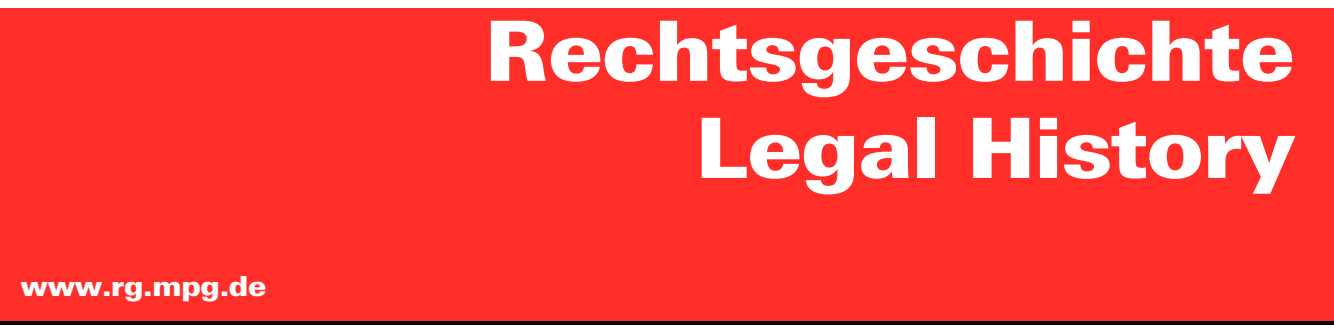

http://www.rg-rechtsgeschichte.de/rg26

$\operatorname{Rg} 202018$

$467-470$

Zitiervorschlag: Rechtsgeschichte - Legal History Rg 26 (2018)

http://dx.doi.org/10.12946/rg26/467-470

\title{
Alejandro Agüero*
}

Words and Acts in the History of Latin American Constitutionalism 
más de cincuenta años, así como detalles sobre las dificultades vividas en la ciudad de Lima durante la Guerra del Pacífico (1879-1883). Esto es también lo que presenta en el último volumen que redacta hasta el final de su vida en 1892, más de setenta años después de su llegada al Perú; lugar donde amasó una importante fortuna.

Witt nos presenta un detallado panorama sobre el siglo diecinueve en el Perú y ya con eso podemos decir que la mayor enseñanza que nos proporciona este trabajo es una mirada de un extranjero noreuropeo que llega a habitar en su interior. Estudios sobre la vida privada, sobre los comerciantes extranjeros, sobre las elites del país, sobre los hábitos de lectura, los viajes tanto dentro como fuera del
Perú se verán enriquecidos con la lectura de Witt. El poder contar con la totalidad de la obra, con estudios que la ponen en contexto es de vital importancia ya que permite que el lector vaya buscando cual es el periodo o el tema de interés. El reto principal, sin embargo, sigue siendo la extensión misma que lleva a que esta sea una colección inmensa y, por ello, costosa y por el otro que necesita de bastante tiempo para lograr una inmersión en el texto. Los beneficios de hacer esta larga lectura son, sin embargo, muchos ya que el lector se ve inmerso en un mundo que ya no existe, llevado por la voz de Witt.

\section{Alejandro Agüero \\ Words and Acts in the History of Latin American Constitutionalism*}

Scholars long held liberal constitutionalism and Latin American politics to be largely incompatible. Either because of the "Spanish legacy« or the social complexity in Latin America, the failure of constitutional/liberal regimes was seen as a peculiar feature of the region's historical development. Against this trend, different voices have emerged since the closing decades of the $20^{\text {th }}$ century. After the so-called "political turn«, the historiographic literature began to reconsider the role of political discourse, constitutions and laws in the aftermath of achieving independence. While some scholars called attention to the liberal tenor of the many constitutions passed in the former Hispanic domains during the first half of the $19^{\text {th }}$ century, others sought to avoid the bias of a model-deviation approach and looked for their original aspects.
This second alternative began with Spanish constitutional history. The historiography of the Cadiz constitution (1812) - conditioned from the beginning by the French model - favored studies focused on its originality.

One striking aspect of that originality was the imperial scope of Cadiz constitutionalism. Cadiz was more a Spanish-American constitution than a Spanish one, and its normative content offered plenty of original solutions. It was a delicate combination of new liberal principles with traditional values as well as practices of government and reformist projects shared by both colonial and metropolitan elites. In this new framework, Cadiz constitutionalism has been qualified as an original experience, a tertium genus before Anglo-American and French-Continental constitutionalism. More-

* José María Portillo Valdés, Historia mínima del constitucionalismo en América Latina, México D. F.:

El Colegio de México 2016, 262 p., ISBN 978-607-462-876-0 
over, Cadiz is just a piece, the most significant perhaps, of a wider constitutional model that has been called »Hispanic constitutionalism«.

This is the context in which we should view the book by José María Portillo, whose title in English would read something like: Minimal History of Constitutionalism in Latin America. In my opinion, the title is not entirely fair to the book's content. While it is a relatively short book on a huge subject, it is not merely a summary of commonplaces nor a simple comparative glimpse. It represents an original attempt to apply the heuristic potential of "Hispanic constitutionalism « to the whole region. Therefore, the book is especially relevant despite its panoramic outlook.

The book is conceived as a »social and political history of Latin-American constitutionalism « (12). Hence, we should not expect the formalist approach typical of jurists who privilege texts at the expense of context. However, as a history of constitutionalism it must be focused on a specific discourse expressed in political speeches, pamphlets, proclamations, law books, laws and constitutions. As a historian committed to the thriving school of critical legal history, Portillo masters the arduous art of relating texts to contexts and walking the fine line that separates rhetoric from praxis.

In his historical approach, Portillo avoids a categorical definition of constitutionalism, identifying its distinctive core in the ideals of social welfare and happiness that prompted deep changes in political rule and state-society relationships. In this sense, by the $18^{\text {th }}$ century constitutionalism was conceived as a discourse directed at achieving the end of despotism, the assurance of rights, and the separation and equilibrium between powers. From this starting point, the next two hundred years were marked, on the one hand, by debates about who to include in those goals (initially restricted to a limited segment of the population - learned Christian men, property holders, etc.); and on the other, by the new sense of welfare that prescribed new objectives for constitutionalism, such as regulating the economy, poverty, unemployment and the social function of private property.

The descriptive tone at the level of the definition is coherent with the socio-historical approach, even though the object is eminently normative. As is well known, the shift from a merely descriptive concept of constitution towards an expressly normative one (i.e. art. XVI of the Declaration of Right of Man, 1789) was a turning point for modern constitutionalism. In that transition, the term was used to mean "good order" and harmony in the body politic. It was in this sense that royal advisors, first in France, then in Spain, warned of the »lack of constitution " during the throes of the ancien régime. While this problem led to revolution in France, in Spain it promoted a reformist program that was finally interrupted by the Napoleonic invasion, the abdications of Bayonne (1808), and the beginning of the wars of independence.

The first chapter makes clear how the convergence of the constitutional problem with imperial collapse in 1808 left early constitutionalism in the Hispanic world with some peculiar traits. At first, it encouraged the original attempt to pass a constitution for the whole empire; soon after, the colonies perceived a need to pass constitutions of their own in pursuit of independence or, as they said, their »emancipation«. In order to fully understand the key notion of »emancipation «, Portillo shows that, besides the Droit de Gens and the Ius Publicum, the effects of the Spanish imperial crisis must be interpreted in light of the Ius Civile. As in parental relationships, the independence of the colonies was viewed in terms of emancipation from the paternal potestas of the king. This perspective sheds light on the peculiar political language of Latin American independence movements.

After 1808, the question of who was entitled to inherit the vacant sovereignty did not have a clear answer. As the kingdom and the colonies did not form a compact nation, the orphanhood of the realm was interpreted as the orphanhood of each of hundreds of communities that felt the opportunity to achieve their emancipation. The imperial collapse triggered an extraordinary process of drafting and passing constitutions throughout the Hispanic world. Portillo characterizes this outcome with a title that evokes a seminal text by Clavero (»As many persons as states «): »as many constitutions as pueblos«. Even in Spain, Portillo argues, the constitution meant emancipation, to the extent that the Cadiz constitution can be read as an attempt to redeem the nation from the paternal potestas of its former kings.

Combining chronological and topical threads, Portillo gives accounts of the different challenges faced by the constitutional culture in the region. The consolidation of the new republics and the arduous work of becoming nations (1820-1860) are the subjects of chapter two. Years of war and 
the dissolution of colonial structures implied severe socio-economic changes with deep political impacts. Militarization of politics, the incorporation of rural populations, and the formation of new elites are just some of the common traits associated with those changes. Ethnic complexity added another complicating condition to new constitutional projects, particularly in setting criteria of exclusion/inclusion for the enjoyment of citizenship rights. Portillo deals with this problem under the question of who were the "persons of the constitutions «. At the same time, the territorial distribution of power is addressed under the question about the "subjects of the constitution «: pueblos, provinces, nations, states.

Constitutional debates and factional confrontations persisted around those issues, while constitutions did not enjoy the expected observance and stability. Still, Portillo highlights the fact that, in such unstable conditions, with caudillos exerting effective power in most of the new republics, the constitutions were needed. Even if they were rather aimed at legitimizing factual situations, they were, formally at least, constitutions. Hence, Portillo concludes that the Latin American caudillismo of the $19^{\text {th }}$ century was a peculiar "constitutional caudillismo « (119). It consisted of a separation into two spheres: that of the law and ordinary matters, and that of the extraordinary and provisional powers conceded to governors. In line with current strands of historiography, Portillo considers that the depiction of caudillos is not complete without that discursive / constitutional aspect.

In a similar way, Portillo gives constitutional meaning to violent collective movements that, evoking the people's power, removed governments and repealed constitutions to pass new ones. Portillo suggests that the pronunciamientos (as these acts were usually called) worked as a "rather factual than juridical « way of exercising rights held by the people, regardless the tenor of the constitutional texts (96). This would mean, then, that instability was inherent to the way in which political actors interpreted the constitutional game.

This way of grasping the relationship among caudillos, pronunciamientos and constitutionalism helps to overcome the recurrent dilemma between rhetoric and praxis. It also avoids the historiographical bias of describing such phenomena as crude violence, proper to a lawless realm, as has been common. Nonetheless, the problem of determining when the justifications of such acts were genuine expressions of constitutional intent and when they were not remains. Can we trust in noble words when even historical actors were aware of the gap between words and acts? In words of José E. Caro (1817-1853), member of the Colombian Conservative Party "the acts were detestable, the names were attractive (apud Calderon and Thibaut, La majestad de los pueblos).

The three final chapters are focused on a) the relative consolidation of liberal republicanism and state-building processes by the late $19^{\text {th }}$ century; b) the crisis of liberalism, the emergence of nationalism, and the revolutions of the early $20^{\text {th }}$ century; and c) populisms, dictatorships, and the new constitutionalism fostered since the 1990s. It was not until the last decades of the $19^{\text {th }}$ century that the new countries' constitutions stabilized. It was the age of a second independence, Portillo says, in reference to the liberal reforms that led, among other things, to emancipate the state from the Catholic Church. Let us recall that, until that time, most of the constitutions enshrined Catholicism as the state religion or fundamental law. These reforms, and others of the kind, became necessary to manage the integration of the region into the trade networks of the Western world.

Paradoxically, the stabilization of liberal regimes, sustained in their economic growth by supplying raw materials to developed countries, did not mean a strengthening of constitutional culture. Portillo observes that this period coincided with a "constitutional devaluation« in parallel with a »dependent and selective modernization« (126). Inequality, exploitation and exclusion for ethnic and cultural reasons continued while executive powers enhanced their control over the legislative and the judiciary. The gap between words and praxis arises again when Portillo, analyzing the Mexican case, concludes that, besides the "nominal constitutionalism « (that of the written Constitution), there was another "political code« that could radically contradict the first (154).

Portillo is aware of the weight of the international context. On the one hand, the devaluation of the constitution was also observable in Continental Europe; on the other, integration in the world trade network set the conditions for a new form of economic imperialism with political intervention, particularly from the USA. At the same time, social tensions increased with the arrival of immigrants that would soon reveal the limits of the oligarchic »liberal« regimes. Fueled by internal and external 
causes, this breeding ground of social unrest encouraged the elites to undertake, in some cases, democratic reforms; in others, revolution was the way out. Portillo compares the experiences of Argentina and Mexico during the second decade of the $20^{\text {th }}$ century, respectively (184).

Despite reforms and revolutions, diverse forms of authoritarianism prevailed until the deep constitutional reforms of the late $20^{\text {th }}$ century. The last chapter tackles this period under the title of "populism, dictatorship and new constitutionalism «. This is not an easy context to grasp, to the extent that the closer the facts are to our own time, the harder it is to discern their historical significance. Let us remark on some examples. Portillo suggests that, unlike earlier authoritarianisms, the dictatorships of the $20^{\text {th }}$ century, especially those of the 1970s and 80s, rejected all constitutional culture and were only sustained by fear and force (210). Nonetheless, there are plenty of cases in which dictatorships claimed to be acting in defense of original constitutional values. And it would be hard to deny that they received support from parts of civil society and, in some cases, from the local authorities of the Catholic Church. We agree in denying any constitutional pretension to these political experiences. The self-justifications in these cases cannot guide the historian. Still, it is hard to explain why those of the preceding century should do so.

Similar concerns come to mind when reading about political experiences like that of Vargas in Brazil or Perón in Argentina. Portillo does not provide an accurate definition of "populism «, nor should we expect him to do so in such a brief book. However, it is worth noting that "populism" has been the subject of a great deal of academic debate in the last decade. Some influential scholars have identified with this term a radicalization of democracy and the condition of possibility for genuine »emancipation«. It would have been interesting to connect this notion in its historical drift with new approaches on populism. If populist experiences were not openly against the constitutions, Portillo suggests that they accorded them only a secondary role. However, according to economic studies, they were unique moments of the democratization of welfare, as was the case of Perón in Argentina.

In such a context, constitutional history becomes somewhat disconcerting. Still, this brief but thorough book offers reasons not to be so skeptical about Latin-American constitutionalism. First, much of the instability and authoritarianism were not exclusive to this region; they also affected, to a great extent, Continental Europe, at least until the end of the World War. Second, without denying the responsibility of Latin American elites, many problems were due to economic imperialism and foreign intervention. Finally, the reforms and the new constitutions passed in recent decades have brought the region, in Portillo's words, into the "vanguard of constitutionalism« (244). Venezuela, Ecuador and Bolivia have led this movement, passing constitutions with new conceptions of rights and guarantees, political freedoms and representative governments. For the first time, constitutions recognize and are addressed to multiethnic, pluricultural and even plurinational societies. Whether these novelties will remain as mere »attractive names« or not, only time will tell. 